\title{
ARBUSCULAR MYCORRHIZAL FUNGI USED TO SUPPORT IRANIAN BARLEY CULTIVATED ON CADMIUM CONTAMINATED SOILS (Hordeum vulgare L.)
}

\author{
Keshavarz, H. $.^{1^{*}}-$ Hosseini, S. J. ${ }^{1}-$ SediBE, M. M. ${ }^{2 *}-$ AChILONU, M. C. ${ }^{3}$ \\ ${ }^{I}$ Tarbiat Modares University, Department of Agronomy, Faculty of Agriculture, Tehran, Iran \\ ${ }^{2}$ Central University of Technology, Free State Department of Agriculture, Private Bag x20539, \\ Bloemfontein, South Africa \\ (phone: +27 51-507-4054) \\ ${ }^{3}$ Mangosuthu University of Technology, Technology Station in Chemical, P.O. Box 12363 \\ Durban, Jacobs 4026, Durban, South Africa \\ ${ }^{*}$ Corresponding authors \\ e-mail:msedibe@cut.ac.za; H.Keshavarz@modares.ac.ir \\ (Received $12^{\text {th }}$ Jul 2021; accepted $28^{\text {th }}$ Oct 2021)
}

\begin{abstract}
To study the effect of arbuscular mycorrhizal fungi (AMF) on the agronomic, physiological, and biochemical parameters of barley (Hordeum vulgare L.) grown on Cd contaminated soils of Iran, an experiment was carried out in Tehran, Iran for two seasons. The results showed that soil Cd caused a significant decrease in leaf area index (LAI), chlorophyll content, 1000 seed weight, and total dry mass per plant, whereas increased proline content, superoxide dismutase, and catalase enzyme activity were elevated by soil Cd. Mycorrhizal fungi significantly reduced the adverse effects of $\mathrm{Cd}$ and increased yield of barley. Decreased proline content, leaf antioxidant activity was also observed where mycorrhizal fungi were used. The use of mycorrhizal fungi had a positive mitigating effect on plant height, 1000 seed weight, chlorophyll contents, proline, LAI, root AMF colonization, foliar cadmium, catalase, peroxidase, and superoxide dismutase. Therefore, AMF have a potential to mitigate the effects of $\mathrm{Cd}$ pollution on soil. These results obtained formed a basis for future studies under open field condition before its application can be recommended to barley production under similar condition.
\end{abstract}

Keywords: antioxidant activity, chlorophyll, yield component, heavy metals, PCA, proline

\section{Introduction}

Cadmium $(\mathrm{Cd})$ is a toxic heavy metal that occurs in nature in minute quantities in association with other natural heavy metal deposits, including $\mathrm{Zn}, \mathrm{Pb}, \mathrm{Cu}$ and others and produced as a byproduct of the mining of major metals. Mining activities are known to generate huge numbers of harmful metals including $\mathrm{Cd}$, which are carried as fugitive dust or by waterways and contaminate the biota and food chain through assimilation and bioaccumulation processes (Ebenebe et al., 2017). Generally, heavy metals present in waterbodies above peamisible limits, not only endanger the lives of aquatic organisms in the waters, but they also make the water courses unsafe for domestic and agricultural uses as well (Tohidi-Moghadam, 2017; Ebenebe et al., 2017). Cadmium is known to be very toxic even at low concentration (Galas-Gorcher, 1991). Studies have shown that human ingestation or exposure to $\mathrm{Cd}$ up to the toxic dose of about $10 \mu \mathrm{g} / \mathrm{dL}$, can cause irritation of the stomach, cramps, nausea, vomiting, diarrhea, headache, brown urine, hypertension, renal failure, flu-like symptoms, kidney and liver damage, swelling of the throat and tingling of hands (Bano and Ashfaq, 2013; Ebenebe et al., 2017). 
Hence, there are various government legislation to control the amount of the toxic metal allowed into the environment to avert unintended poisoning of the biota. The critical limit of $\mathrm{Cd}$ metal in light, medium, and heavy textured soils is 5.33, 6.33 and $9.29 \mathrm{mg} \mathrm{kg}^{-1}$, respectively (Keshavarz, 2020). Through food products, Europe and North America allow daily intake of about $15-25 \mathrm{Cd} \mu \mathrm{g}$, while in Japan the average allowed intake is between 40 and $50 \mathrm{Cd} \mu \mathrm{g}$ (WHO, 2000). The intake of $\mathrm{Cd}$ is found to be higher in Cd polluted areas. World average Cd obtained via food products is about $1 \mu \mathrm{g} / \mathrm{day}$ (Bano and Ashfaq, 2013).

The absorption and accumulation of $\mathrm{Cd}$ on plants is influenced by the soil conditions and the interaction between $\mathrm{Cd}$ and other minerals (Wang et al., 2016). Mycorrhizal fungi ameliorates plant yield by increasing water and nutrient uptake (Pharudi, 2010). According to Azcon-Aguilar and Barea (1997), the efficiency and activity of soil microbes are affected by rhizosphere conditions, including the level of salinity, moisture content and fertility. Extensive extra-radical hyphae network enhances efficiency in the absorption of nutrients and in close association with plant root hair playing an important symbiotic role in the uptake and transfer of water and nutrients by the root system. In exchange, the plant supplies the fungal organism with carbon compound (Gadd, 2004). These fungi reduce the concentration of heavy metals in the cell wall by binding the heavy metal to chitin and secreting glomalin and reduce the accumulation of heavy metals by coexisting with plants (Gadd, 2004).

The upper limit of cadmium allowed in root, tuber and leafy vegetables in Australia is $0.1 \mathrm{mg}$ of cadmium per $\mathrm{kg}$ of produce and in Iran, there is no policy regulating Cd levels on food stuff and soil (Tavakkoli and Khanjani. 2016). Cadmium in soils is generally low but once it has been added to the soil through pollution, it can take between 100 and 1000 years for the levels to drop by $50 \%$. When Cd is present in soil, it is more available to plants if the soil is sandy, acidic or low in organic matter (Tavakkoli and Khanjani, 2016).

Plants accumulates harmful metal over time, that eventually affect the plants' activities such as nutrient absorption and photosynthesis. The hampering of the plants ability to absorb nutrients results to leaf decoloration, growth inhibition, poor yields, and eventual death of the plant (Ebenebe et al., 2017). However, the symbioses of some soil microbes and plants, help to restore soils that have been impoverished by toxic heavy metals (Qiu et al., 2018). Studies have established that AMF is effective, not only in restoration/bioremediation of soils polluted by heavy metals such as $\mathrm{Cd}$, but the microbes also improve availability of nutrients, activities of enzymes and fertility of the soil (Qiu et al., 2018; Keshavarz, 2020). Due to the vital role of cereals in human diet, it is essential to find ways that can be used to reduce Cd uptake by cultivated plants (Shi et al., 2019). Therefore, the effect of AMF Rhizophagus intraradices (also known as Glomus intraradices) species on Cd contaminated soil of Iran was evaluated on agronomic, physiological, and biochemical parameters of barley.

\section{Material and methods}

\section{Research site}

This experiment was conducted in a greenhouse of Tarbiat Modares University farm located in Tehran, Iran. The latitude of the research farm is 35.325241, and the longitude is 51.647198 category with the GPS coordinates of $35^{\circ} 19^{\prime} 30.8676^{\prime \prime} \mathrm{N}$ and $51^{\circ} 38^{\prime}$ $49.9128^{\prime \prime}$ E. The study was conducted in 2020 using a $2 \times 4$ factorial design where, two levels of AMF (applied at zero and $20 \mathrm{mg} \mathrm{plant}^{-1}$ ) and 4 levels of cadmium applied zero 
mg kg-1 soil (control), $40 \mathrm{mg} \mathrm{kg}^{-1}$ soil, $80 \mathrm{mg} \mathrm{kg}^{-1}$ of soil, and $120 \mathrm{mg} \mathrm{kg}^{-1}$ of soil. This experiment had three replications and Rhizophagus intraradices was the only AMF used. The greenhouse was equipped with cool white fluorescent lamps and had a day and night temperature 22 and $20{ }^{\circ} \mathrm{C}$, respectively, containing 16/8 hr light/dark photoperiod. The potting sandy loam soil had $0.02 \%-\mathrm{N}, 556.4-\mathrm{K} \mathrm{mg} \mathrm{kg}^{-1}, 8.7-\mathrm{P} \mathrm{mg} \mathrm{kg}^{-1}, 3.98-\mathrm{Fe} \mathrm{mg} \mathrm{kg}{ }^{-1}$, 7.01-Mn mg kg-1, 2.2-Cu mg kg-1 and 0.52-Zn mg kg-1, 7.1-pH and $0.47 \mathrm{dS} / \mathrm{m}-\mathrm{EC}$.

\section{Parameters}

Five plants per treatments were used to measure plant height, number of grains per panicle, 1000 seed weight, total dry mass, chlorophyll contents, proline concentration, leaf area index (LAI), leaf cadmium and phosphorus content, colonization percentage, peroxidase activity (POX), malondialdehyde (MDA) and superoxide dismutase activity (SOD). Chlorophyll content was measured on young and fully developed leaves using the method described by Arnon (1949). LAI was measured using a Delta-T Devices leaf area meter (Delta-T Devices Ltd., Cambridge, UK).

Leaves of barley were freeze-dried using liquid nitrogen $\left(-80^{\circ} \mathrm{C}\right)$ thereafter, $0.3 \mathrm{~g}$ were milled using $5 \mathrm{~mL}$ of $50 \mathrm{mM}$ phosphate buffer (pH 7.0). SOD, CAT and POX activity were determined using a method of Giannopolitis and Ries (1977), Cakmak and Horst (1991) and Ghanati et al. (2002), respectively. The content of MDA of the extracts was calculated using De Vos et al. (1991) method. Proline content was determined using Bates et al. (1973) method.

Analysis of variance was performed using SAS and Excel, and the means were compared using LSD test at $\mathrm{P}<0.05$. All analysis was performed by using the SAS (SAS release 9.0 2002) software. Principal Component Analysis (PCA) based on biplot (SAS 9.1) and coefficient of correlation were applied to consider the visualization of similarities or differences and interrelationships by acute and obtuse angles among all parameters.

\section{Results and discussion}

As shown in Table 1, plant height $(\mathrm{p}<0.0001)$, number of grains per panicle $(p<0.0001), 1000$ seed weight $(p<0.0001)$, total dry mass $(p<0.001)$ and chlorophyll contents $(\mathrm{p}<0.0001)$ were affected by the concentration of $\mathrm{Cd}$ in the soil. Plant height, number of grains per panicle, 1000 seed weight, chlorophyll contents and LAI were reduced by $14.68 \%, 26.85 \%, 12.24 \%, 36.31 \%, 20.85 \%$ and $7.28 \%$, respectively. Despite this decline, the use of AMF increased plant height $(\mathrm{p}<0.05)$, number of grains per panicle $(p<0.0001), 1000$ seed weight $(p<0.0001)$, chlorophyll contents $(p<0.0001)$ and LAI $(\mathrm{p}<0.001)$. Unexpectedly, no significant effect of AMF was found on the number of grains per panicle, and total dry mass of barley. Dhir et al. (2009) reported that reduction of leaf chlorophyll is attributed to Fe content reduction and the decrease of enzyme efficiency involved in chlorophyll biosynthesis. Pandey and Sharma (2002) further reported that increased $\mathrm{Ni}$, and Co concentration in the soil led to a significant reduction in chlorophyll "a" and "b" contents measured in cabbage (Brassica oleracea L). Increased chlorophyll content in mycorrhizae inoculated plants is attributed to improved $\mathrm{P}$ and $\mathrm{N}$ uptake. In contrast, leaf $\mathrm{P}$ was not increased by mycorrhizal fungi (Table 1). However, application of AMF improved chlorophyll contents by $4.54 \%$, these results were in agreement with Pereira et al. (2012), who reported increased chlorophyll a and b by $23 \%$ and $38 \%$ respectively in chestnut (Castanea alnifolia). In addition, AMF reduce active uptake of heavy metals through the roots while maintaining active uptake of other elements such as 
$\mathrm{N}$ and phosphorus (Neumann and George, 2005). Heavy metals affect homeostasis processes such as water uptake, transport, transpiration, and metabolism of nutrients and uptake of N, P, K, Ca, and magnesium (Tripathi et al., 2014).

Table 1. Effect of soil Cd and mycorrhizal fungi on agronomic physiological parameters of barley

\begin{tabular}{|c|c|c|c|c|c|c|c|}
\hline Treatment & $\begin{array}{c}\text { Plant } \\
\text { height } \\
(\mathbf{c m})\end{array}$ & $\begin{array}{c}\text { Number of } \\
\text { seed } \\
\text { panicle }^{-1} \\
\end{array}$ & $\begin{array}{c}1000 \text { seed } \\
\text { weight } \\
\left(\text { g plant }^{-1}\right)\end{array}$ & $\begin{array}{l}\text { Dry mass } \\
\left(\text { g plant }^{-1}\right)\end{array}$ & $\left|\begin{array}{l}\text { Chlorophyll } \\
\left(\mathrm{mg} \mathrm{g}^{-1} \text { FW) }\right.\end{array}\right|$ & $\begin{array}{c}\text { Proline } \\
\left(\mathrm{mg} \mathrm{g}^{-1} \mathrm{FW}\right)\end{array}$ & $\begin{array}{l}\text { Leaf area } \\
\text { index }\end{array}$ \\
\hline \multicolumn{8}{|l|}{$\begin{array}{l}\text { Cadmium } \\
\left(\mathrm{mg} \mathrm{kg}^{-1}\right)\end{array}$} \\
\hline $\begin{array}{c}0 \\
40 \\
80 \\
120 \\
\text { LSD }_{0.05} \\
\end{array}$ & \begin{tabular}{|c|}
$72.28 \pm 2.22^{\mathrm{a}}$ \\
$68.65 \pm 2.09^{\mathrm{b}}$ \\
$64.93 \pm 2.15^{\mathrm{c}}$ \\
$61.66 \pm 2.9^{\mathrm{d}}$ \\
$2.47^{* * * *}$ \\
\end{tabular} & $\begin{array}{c}41.03 \pm 2.72^{\mathrm{a}} \\
37.85 \pm 4.45^{\mathrm{ab}} \\
33.72 \pm 3.94^{\mathrm{bc}} \\
30.01 \pm 4.86^{\mathrm{c}} \\
5.64^{* * * *}\end{array}$ & $\begin{array}{c}41.90 \pm 0.80^{\mathrm{a}} \\
40.20 \pm 1.10^{\mathrm{b}} \\
38.16 \pm 1.38^{\mathrm{c}} \\
36.7 \pm 1.99^{\mathrm{d}} \\
1.35^{* * *}\end{array}$ & \begin{tabular}{|c}
$30.43 \pm 2.88^{\mathrm{a}}$ \\
$26.54 \pm 3.89^{\mathrm{ab}}$ \\
$23.94 \pm 3.82^{\mathrm{bc}}$ \\
$19.38 \pm 3.62^{\mathrm{c}}$ \\
$4.6^{* *}$ \\
\end{tabular} & $\begin{array}{c}1.87 \pm 0.03^{\mathrm{a}} \\
1.81 \pm 0.06^{\mathrm{b}} \\
1.71 \pm 0.05^{\mathrm{c}} \\
1.48 \pm 0.05^{\mathrm{d}} \\
0.047^{* * *}\end{array}$ & $\begin{array}{c}1.15 \pm 0.15^{\mathrm{d}} \\
2.45 \pm 0.45^{\mathrm{c}} \\
3.16 \pm 0.39^{\mathrm{b}} \\
3.81 \pm 0.33^{\mathrm{a}} \\
0.27^{* * * *} \\
\end{array}$ & $\begin{array}{c}6.86 \pm 0.06^{\mathrm{a}} \\
6.51 \pm 0.05^{\mathrm{b}} \\
6.36 \pm 0.08^{\mathrm{c}} \\
6.76 \pm 0.07^{\mathrm{d}} \\
0.067^{* * *} \\
\end{array}$ \\
\hline \multicolumn{8}{|c|}{\begin{tabular}{l|l|l|} 
Mycorrhizae & & \\
\end{tabular}} \\
\hline $\begin{array}{l}\text {-Myco } \\
+ \text {-Myco } \\
\text { LSD }_{0.05}\end{array}$ & \begin{tabular}{|c|}
$65.67 \pm 4.61^{\mathrm{b}}$ \\
$68.09 \pm 4.30^{\mathrm{a}}$ \\
$1.74^{*}$ \\
\end{tabular} & $\begin{array}{c}34.55 \pm 5.99^{\mathrm{a}} \\
36.74 \pm 5.44^{\mathrm{a}} \\
3.98^{\mathrm{ns}} \\
\end{array}$ & $\begin{array}{c}38.37 \pm 2.61^{\mathrm{b}} \\
40.10 \pm 1.88^{\mathrm{a}} \\
0.96^{* *}\end{array}$ & $\begin{array}{c}23.57 \pm 5.52^{\mathrm{a}} \\
26.58 \pm 4.79^{\mathrm{a}} \\
3.20^{\mathrm{ns}} \\
\end{array}$ & $\begin{array}{c}1.68 \pm 0.16^{\mathrm{b}} \\
1.76 \pm 0.15^{\mathrm{a}} \\
0.03^{* *} \\
\end{array}$ & $\begin{array}{c}2.89 \pm 1.13^{\mathrm{a}} \\
2.40 \pm 0.97^{\mathrm{b}} \\
0.19^{* * * *} \\
\end{array}$ & $\begin{array}{c}6.40 \pm 0.31^{\mathrm{b}} \\
6.50 \pm 0.28^{\mathrm{a}} \\
0.05^{* *} \\
\end{array}$ \\
\hline \multicolumn{8}{|c|}{\begin{tabular}{l|l} 
Cadmium $\times$ \\
Mycorrhizae
\end{tabular}} \\
\hline \multirow[t]{2}{*}{$\mathrm{LSD}_{0.05}$} & $3.49^{\text {ns }}$ & $7.97^{\mathrm{ns}}$ & $1.92^{\mathrm{ns}}$ & $6.58^{\mathrm{ns}}$ & $0.07^{\mathrm{ns}}$ & $0.38^{\mathrm{ns}}$ & $0.09^{\mathrm{ns}}$ \\
\hline & $\begin{array}{c}\text { Cadmium } \\
\left(\mathrm{mg} \mathrm{kg}^{-1}\right. \\
\mathrm{DW})\end{array}$ & $\begin{array}{c}\text { Colonization } \\
(\%)\end{array}$ & $\begin{array}{c}\text { CAT }(\Delta \text { Abs } \\
\text { mg protein } \\
\left.\text { min }^{-1}\right)\end{array}$ & $\begin{array}{c}\text { Leaf-P } \\
\text { content } \\
\left(\mathrm{mg} \mathrm{kg}^{-1}\right. \\
\text { DW) }\end{array}$ & $\begin{array}{c}\operatorname{POX}(\Delta \text { Abs } \\
\text { mg protein } \\
\left.\text { min }^{-1}\right)\end{array}$ & $\begin{array}{c}\text { MAD }(\mu \mathrm{mol} \\
\left.\mathrm{g}^{-1} \mathrm{FW}\right)\end{array}$ & $\begin{array}{c}\text { SOD }(\Delta \text { Abs } \\
\text { mg protein } \\
\left.\text { min }^{-1}\right)\end{array}$ \\
\hline \multicolumn{8}{|l|}{$\begin{array}{l}\text { Cadmium } \\
\left(\mathrm{mg} \mathrm{kg}^{-1}\right)\end{array}$} \\
\hline $\begin{array}{c}0 \\
40 \\
80 \\
120 \\
\text { LSD }_{0.05} \\
\end{array}$ & $\begin{array}{c}0.82 \pm 0.13^{\mathrm{d}} \\
3.73 \pm 0.66^{\mathrm{c}} \\
5.01 \pm 0.54^{\mathrm{b}} \\
6.26 \pm 5.28^{\mathrm{a}} \\
0.20^{* * * *} \\
\end{array}$ & $\begin{array}{c}42.59 \pm 32.45^{\mathrm{a}} \\
40.65 \pm 29.34^{\mathrm{a}} \\
38.84 \pm 25.4^{\mathrm{a}} \\
36.91 \pm 25.46^{\mathrm{a}} \\
4.16^{\mathrm{ns}} \\
\end{array}$ & \begin{tabular}{|c|}
$52.23 \pm 4.80^{\mathrm{d}}$ \\
$121.74 \pm 14.70^{\mathrm{c}}$ \\
$146.33 \pm 18.67^{\mathrm{b}}$ \\
$165.12 \pm 19.49^{\mathrm{a}}$ \\
$9.92^{* * *}$ \\
\end{tabular} & $\begin{array}{c}3.65 \pm 0.29^{\mathrm{a}} \\
3.85 \pm 0.31^{\mathrm{a}} \\
2.39 \pm 0.32^{\mathrm{b}} \\
2.67 \pm 0.36^{\mathrm{b}} \\
0.431^{* * *} \\
\end{array}$ & \begin{tabular}{|c|}
$2.32 \pm 0.14^{\mathrm{d}}$ \\
$8.18 \pm 0.63^{\mathrm{c}}$ \\
$11.09 \pm 0.75^{\mathrm{b}}$ \\
$13.39 \pm 0.89^{\mathrm{a}}$ \\
$0.27^{* * *}$ \\
\end{tabular} & \begin{tabular}{|c|}
$8.37 \pm 1.96^{\mathrm{c}}$ \\
$9.14 \pm 1.88^{\mathrm{bc}}$ \\
$10.91 \pm 1.92^{\mathrm{ab}}$ \\
$13.11 \pm 1.52^{\mathrm{a}}$ \\
$2.35^{* *}$ \\
\end{tabular} & \begin{tabular}{|c}
$111.16 \pm 14.60^{\mathrm{d}}$ \\
$322.46 \pm 293.85^{\mathrm{c}}$ \\
$451.6 \pm 32.42^{\mathrm{b}}$ \\
$492.1 \pm 22.49^{\mathrm{a}}$ \\
$20.7^{* * * *}$ \\
\end{tabular} \\
\hline \multicolumn{8}{|c|}{\begin{tabular}{c|c|c|} 
Mycorrhizae & & \\
$(20 \mathrm{~mL}$ & & \\
plant $\left.^{-1}\right)$ & & \\
\end{tabular}} \\
\hline $\begin{array}{l}\text {-Myco } \\
+ \text { Myco } \\
\text { LSD } 0.05\end{array}$ & \begin{tabular}{|c|}
$.361 \pm 2.27^{\mathrm{a}}$ \\
$3.55 \pm 1.95^{\mathrm{b}}$ \\
$0.14^{* * *}$
\end{tabular} & $\begin{array}{l}14.17 \pm 3.08^{\mathrm{b}} \\
65.32 \pm 5.64^{\mathrm{a}} \\
2.94^{* * * *}\end{array}$ & $\begin{array}{c}133.07 \pm 50.29^{\mathrm{a}} \\
109.61 \pm 40.02^{\mathrm{b}} \\
7.01^{* * *}\end{array}$ & $\begin{array}{c}3.02 \pm 0.68^{\mathrm{a}} \\
3.26 \pm 0.74^{\mathrm{a}} \\
0.31^{\mathrm{ns}}\end{array}$ & $\begin{array}{c}9.27 \pm 4.60^{\mathrm{a}} \\
8.22 \pm 4.05^{\mathrm{b}} \\
0.19^{* * *}\end{array}$ & \begin{tabular}{|c|}
$11.20 \pm 2.52^{\mathrm{a}}$ \\
$9.57 \pm 2.35^{\mathrm{a}}$ \\
$1.66^{\mathrm{ns}}$
\end{tabular} & $\begin{array}{c}363.34 \pm 160.01^{\mathrm{a}} \\
325.33 \pm 151.41^{\mathrm{b}} \\
14.64^{* * * *}\end{array}$ \\
\hline \multicolumn{8}{|l|}{$\begin{array}{l}\text { Cadmium } \times \\
\text { Mycorrhizae }\end{array}$} \\
\hline $\mathrm{LSD}_{0.05}$ & $0.28^{* *}$ & $5.88^{*}$ & $14.03^{\text {ns }}$ & $0.61^{\mathrm{ns}}$ & $0.38^{* *}$ & $3.327^{\mathrm{ns}}$ & $29.28^{\mathrm{ns}}$ \\
\hline
\end{tabular}

Statistical significance was at $0.05 \mathrm{p}$ value. $* * *=\mathrm{p}<0.0001,{ }^{* *} \mathrm{p}<0.001,{ }^{*} \mathrm{p}<0.05$, ns $=$ not significant at $p<0.05, \pm$ standard deviation, LSD $=$ Least significant difference at $5 \%$ level of significance. Means with the same letter used as superscripts within a column are not significantly different $(\mathrm{p}<0.05),-\mathrm{Myco}=$ zero mycorrhizae, + Myco $=$ mycorrhizae applied at $20 \mathrm{~mL} \mathrm{plant}^{-1}$

Table 1 shows foliar $\mathrm{Cd}$ and $\mathrm{P}$ contents were reduced by $\mathrm{Cd}$ toxicity. Foliar $\mathrm{Cd}$ content was reduced by $278 \%, 17.68 \%$, and $5.8 \%$ in soils that had 40,80 , and $120 \mathrm{mg} \mathrm{Cd} \mathrm{kg}^{-1}$ (Table 1, Fig. 1). These results are supported by work done on Lactuca sativa (L.) where leaf $\mathrm{Cd}$ was lowered by AMF at the same time plant growth was increased (Cozzolino et al., 2010). At a higher level, $\mathrm{Cd}$, competes with $\mathrm{P}$ in the cytoplasm affecting the physiological processes of the plant cell, which reduces phosphorus uptake, due to the similarity of $\mathrm{Cd}$ and mineral phosphate (Zhao et al., 2010). A negative relationship 
occurred between $\mathrm{P}$ and $\mathrm{Cd}$ in shoots in both zero AMF $(\mathrm{r}=-0.62 * *)$ and AMF use $\left(\mathrm{r}=-0.70^{* *}\right)$ treatments (Table 2). As an indication of stress, the proline levels were increased with increasing levels of $\mathrm{Cd}$. This is an indication that barley production can be improved on Cd polluted soil using AMF; thus, the observed proline increase was to protect plants against the stress caused by soil Cd toxicity (Ullah, 2016). Proline protects the cell membranes and proteins from the oxidative stress of hydroxyl ions and superoxide ions through chemical and physical processes (Keshavarz et al., 2016).

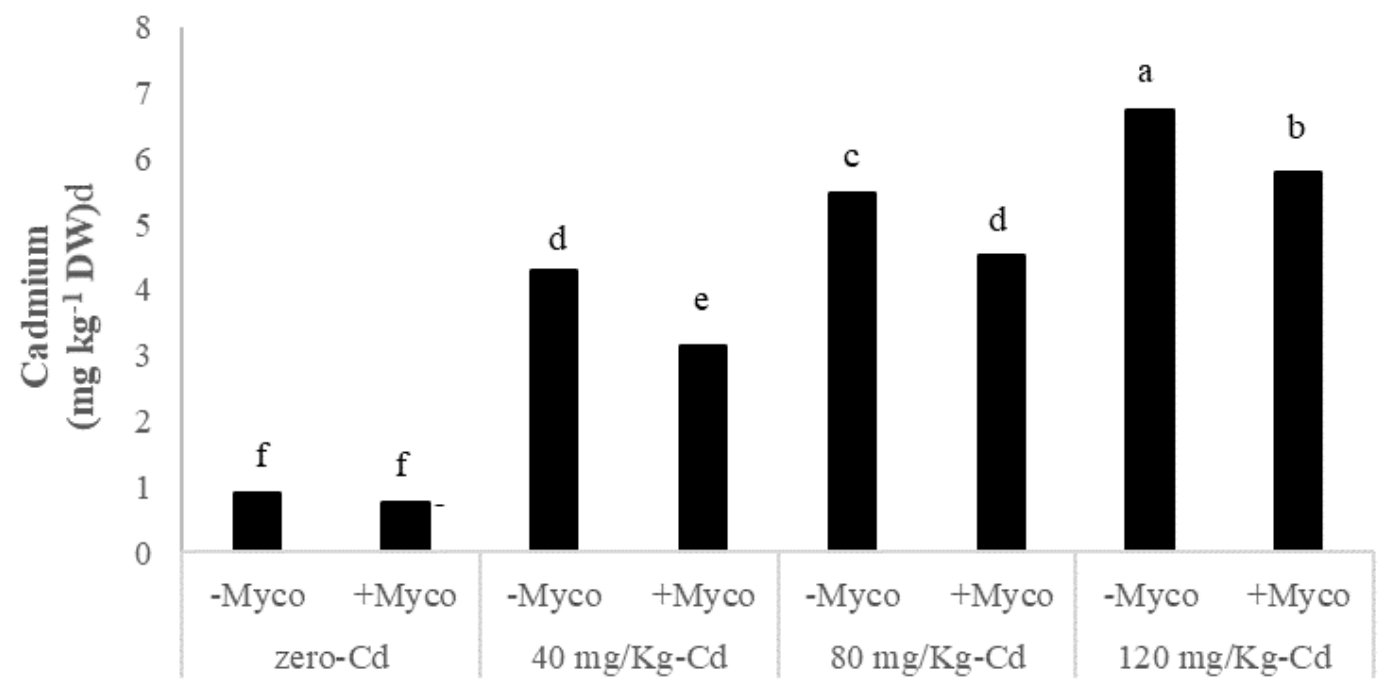

Figure 1. Foliar Cd of barley grown on Cd polluted soil amended with mycorrhizal fungi (Myco = zero mycorrhizae, + Myco= mycorrhizae applied at $\left.20 \mathrm{~mL} \mathrm{plant}^{-1}\right)$

AMF colonization of the root was affected significantly $(\mathrm{p}<0.05)$ by the interaction between $\mathrm{Cd}$ and mycorrhizal fungi as depicted in Fig. 2. Fungal colonization was increased where AMF was used. Javaid (2009) study showed a contrary effect to our study of Cd polluted soil on mycorrhizal fungi. On the other hand, Garg et al. (2015) and Al-Agely et al. (2005) reported an increase in root colonization by AMF under Cd toxicity. These differences in plant response to inoculation is attributed to the type of host plant, environmental conditions and the amount of energy provided by the host.

Table 1 shows that CAT $(\mathrm{p}<0.0001)$, SOD $(\mathrm{p}<0.0001)$, and MDA were significantly increased by increasing levels of Cd contamination, however the activity of SOD and CAT were decreased where mycorrhizal fungi was used. Superoxide dismutase is a key enzyme for protecting cells against oxidative stress, it accelerates the conversion of $\mathrm{O}_{2}{ }^{-}$ to $\mathrm{H}_{2} \mathrm{O}_{2}$ and $\mathrm{O}_{2}$. Research by Parlak (2016) showed that increasing Ni concentration increased the activity of superoxide dismutase in barley seedlings. In this study, the use of mycorrhizae in different levels of Cd reduced the enzymatic activity, which can be attributed to the development of root volume and increased water availability (Neumann and George, 2005). Therefore, as the stress level decreases, the production of oxygen free radicals decreases, and the activity of the leaf superoxide dismutase enzyme decreases (Ullah, 2016). 
Table 2. Pearson correlation coefficients between measured parameters of barley cultivated on Cd contaminated soils

\begin{tabular}{|c|c|c|c|c|c|c|c|c|c|c|c|c|c|}
\hline & Parameters & $\begin{array}{c}\text { Root } \\
\text { colonization }\end{array}$ & LAI & Chlorophyll & MDA & Proline & Cadmium & Phosphorous & Catalase & Peroxidase & SOD & $\begin{array}{c}100 \text { seed } \\
\text { weight }\end{array}$ & $\begin{array}{l}\text { Dry } \\
\text { mass }\end{array}$ \\
\hline \begin{tabular}{c|} 
\\
Zero \\
mycorrhizal \\
inoculation
\end{tabular} & \begin{tabular}{|c|} 
Root colonization \\
LAI \\
Chlorophyll \\
Malondialdehyde \\
Proline \\
Cadmium \\
Phosphorous \\
Catalase \\
Peroxidase \\
SOD \\
1000 seed weight \\
Dry mass
\end{tabular} & $\begin{array}{c}1 \\
-0.18^{\mathrm{ns}} \\
-0.13^{\mathrm{ns}} \\
0.37^{\mathrm{ns}} \\
0.26^{\mathrm{ns}} \\
0.17^{\mathrm{ns}} \\
-0.09^{\mathrm{ns}} \\
0.21^{\mathrm{ns}} \\
0.26^{\mathrm{ns}} \\
0.20^{\mathrm{ns}} \\
-0.16^{\mathrm{ns}} \\
0.20^{\mathrm{ns}}\end{array}$ & $\begin{array}{c}1 \\
0.95^{* *} \\
-0.70^{* *} \\
-0.95^{* *} \\
-0.96^{* *} \\
0.62^{*} \\
-0.94^{* *} \\
-0.95^{* *} \\
-0.97^{* *} \\
0.89^{* *} \\
0.77^{* *}\end{array}$ & $\begin{array}{c}1 \\
-0.70^{* *} \\
-0.87^{* *} \\
-0.86^{* *} \\
0.63^{*} \\
-0.83^{* *} \\
-0.84^{* *} \\
-0.88^{* *} \\
0.83^{* *} \\
0.77^{* *}\end{array}$ & $\begin{array}{c}1 \\
0.59^{*} \\
0.61^{*} \\
0.43^{\mathrm{ns}} \\
0.60^{*} \\
0.67^{*} \\
0.65^{*} \\
0.74^{* *} \\
-0.16^{\mathrm{ns}}\end{array}$ & $\begin{array}{c}1 \\
0.97^{* *} \\
-0.64^{*} \\
0.96^{* *} \\
0.97^{* *} \\
0.93^{* *} \\
-0.87^{* *} \\
-0.77^{* *}\end{array}$ & $\begin{array}{c}1 \\
-0.62^{*} \\
0.99^{* *} \\
0.98^{* *} \\
0.99^{\text {** }} \\
-0.89^{\text {** }} \\
-0.77^{\text {** }}\end{array}$ & $\begin{array}{c}1 \\
-0.68^{*} \\
-0.61^{*} \\
-0.66^{*} \\
0.65^{*} \\
0.63^{*}\end{array}$ & $\begin{array}{c}1 \\
0.97^{* *} \\
0.98^{* *} \\
-0.89^{* *} \\
-0.75^{* *}\end{array}$ & $\begin{array}{c}1 \\
0.99^{\text {** }} \\
0.88^{\text {** }} \\
-0.68^{*}\end{array}$ & $\begin{array}{c}1 \\
-0.91^{* *} \\
-0.77^{* *}\end{array}$ & $\begin{array}{c}1 \\
0.67^{*}\end{array}$ & 1 \\
\hline \begin{tabular}{c|}
$20 \mathrm{ml}$ \\
mycorrhizal \\
inoculation
\end{tabular} & \begin{tabular}{|c|} 
Root colonization \\
LAI \\
Chlorophyll \\
Malondialdehyde \\
Proline \\
Cadmium \\
Phosphorous \\
Catalase \\
Peroxidase \\
SOD \\
100 seed weight \\
weight \\
Dry mass
\end{tabular} & $\begin{array}{c}1 \\
0.85^{\text {** }} \\
0.74^{\text {** }} \\
-0.63^{*} \\
-0.84^{* *} \\
-0.88^{* *} \\
0.72^{\text {** }} \\
-0.88^{* *} \\
-0.89^{* *} \\
-0.85^{* *} \\
0.64^{*} \\
0.77^{* *}\end{array}$ & $\begin{array}{c}1 \\
0.90^{* *} \\
-0.86^{* *} \\
-0.95^{* *} \\
-0.97^{* *} \\
0.63^{*} \\
-0.95^{* *} \\
-0.95^{* *} \\
-0.96^{* *} \\
0.83^{* *} \\
0.74^{*}\end{array}$ & $\begin{array}{c}1 \\
-0.87^{* *} \\
-0.86^{* *} \\
-0.85^{* *} \\
0.61^{*} \\
-0.77^{* *} \\
-0.76^{* *} \\
-0.81^{* *} \\
0.72^{* *} \\
0.70^{*} \\
\end{array}$ & $\begin{array}{c}1 \\
0.83^{* *} \\
0.81^{* *} \\
-0.64^{*} \\
0.77^{* *} \\
0.80^{* *} \\
0.78^{* *} \\
-0.85^{\text {** }} \\
-0.38^{\mathrm{ns}}\end{array}$ & $\begin{array}{c}1 \\
0.97^{\text {** }} \\
-0.70^{\text {** }} \\
0.95^{\text {** }} \\
0.92^{\text {** }} \\
0.97^{\text {** }} \\
-0.87^{\text {** }} \\
-0.77^{\text {** }}\end{array}$ & $\begin{array}{c}1 \\
-0.70^{* *} \\
0.99^{* *} \\
0.96^{\text {** }} \\
0.99^{\text {** }}\end{array}$ & $\begin{array}{c}1 \\
-0.72^{* *} \\
-0.64^{*} \\
-0.69^{*} \\
0.73^{* *}\end{array}$ & $\begin{array}{c}1 \\
0.97^{\text {** }} \\
0.99^{\text {** }}\end{array}$ & $\begin{array}{c}1 \\
0.97^{* *} \\
-0.84^{* *} \\
-0.69^{*}\end{array}$ & $\begin{array}{c}1 \\
-0.88^{* *} \\
-0.79^{* *}\end{array}$ & $\begin{array}{c}1 \\
0.56^{\mathrm{ns}} \\
\end{array}$ & 1 \\
\hline
\end{tabular}

Statistical significance was at $0.05 \mathrm{p}$ value. $* * *=\mathrm{p}<0.0001, * * \mathrm{p}<0.001, * \mathrm{p}<0.05$, ns $=$ not significant at $\mathrm{p}<0.05$ 


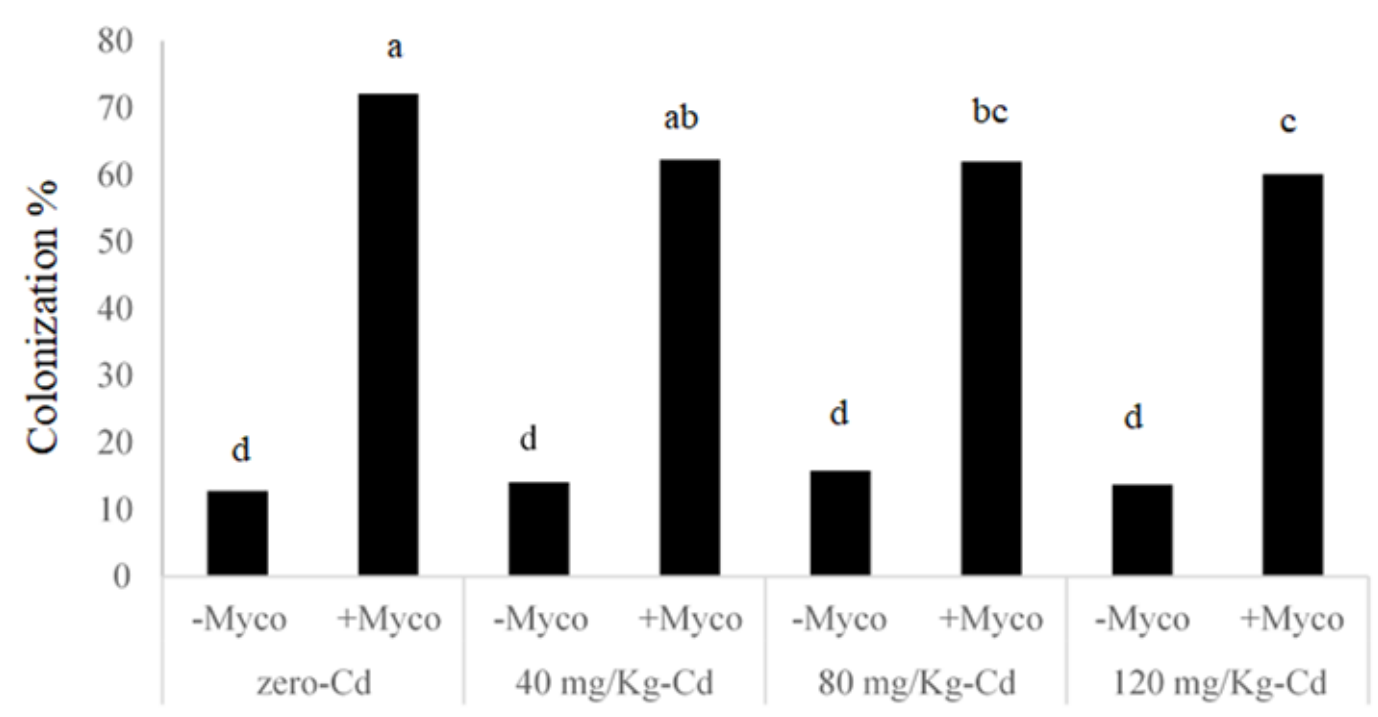

Figure 2. Mycorrhizal root colonisation of barley grown on Cd polluted soil amended with mycorrhizal fungi $\left(-M y c o=\right.$ zero mycorrhizae,+ Myco $=$ mycorrhizae applied at $20 \mathrm{~mL}$ plant $\left.^{-1}\right)$

Table 1 and Fig. 3 shows a significant interaction, that is the activity of POX was significantly increased by soil Cd, its activity was increased by $31.63 \%$ at the same time it was decreased by AMF inoculum. The levels of CAT and POX were increased with increasing levels of soil $\mathrm{Cd}$ and were both decreased by the use of mycorrhizal fungi. Previously an increased activity of the antioxidant enzymes catalase and peroxidase under the $\mathrm{Cd}, \mathrm{Hg}, \mathrm{Ni}$, and $\mathrm{Pb}$ stress was reported (Azcon-Aguilar et al., 1997). Increased activity of catalase can be due to the fact that these enzymes are involved in the antioxidant defense system of plants under oxidative stress caused by heavy metals (TohidiMoghaddam, 2017). CAT and POX are other important enzymes that are activated under stress. These enzymes are able to digest and remove hydrogen peroxide $\left(\mathrm{H}_{2} \mathrm{O}_{2}\right)$ (Khatun et al., 2008). Thus, hydrogen peroxide $\left(\mathrm{H}_{2} \mathrm{O}_{2}\right)$, which is a toxic product of SOD function, is used by these enzymes (Keshavarz et al., 2016). Arbuscular mycorrhizal fungi help the host plant to absorb nutrients, but also improve the tolerance of the plant to nonenvironmental environmental factors (Jahromi et al., 2008). These fungi reduce the concentration of heavy metal in the cell wall by binding heavy metal to chitin (Hildebrandt et al., 2007) and glomalin secretion (González-Chávez et al., 2004; Wang et al., 2016). Therefore, it seems that AMF reduce the activity of CAT and POX by reducing the absorption of heavy metals and thus reducing the oxidative stress caused by the absorption of heavy metals. Plants grown in the presence of heavy metals showed a decrease in water uptake, photosynthesis, nutrient uptake, and 1000 seed weight. The use of mycorrhizae can cause the development of longitudinal meristems of the roots and reduce the activity of catalase and peroxidase of leaves.

Table 3 shows the PCA used to reduce the redundancy interaction between $\mathrm{Cd}$ and mycorrhizal data, and the eigenvalue of correlation matrix. Table 3 and Fig. 4 show the interaction between $\mathrm{Cd}$ and $\mathrm{AMF}$ treatment, out of fourteen principal components (PC) used, the first two (PC1 and PC2) accounted for most of the variability, with a cumulative variability $>77.01 \%$. PC1 accounted for $77.02 \%$, while PC2 accounted for $7.12 \%$ of the total variance. Table 3 and Fig. 4 show that plant height, number of grains, 1000 seed weight, total dry mass, chlorophyll, proline, SOD, CAT, P, POX, LAI, MDA, leaf Cd 
content, were loaded positively on PC1, however only colonization was loaded on PC2. This is an indication that mycorrhizal can be used to mitigate against Cd pollution in the soil.

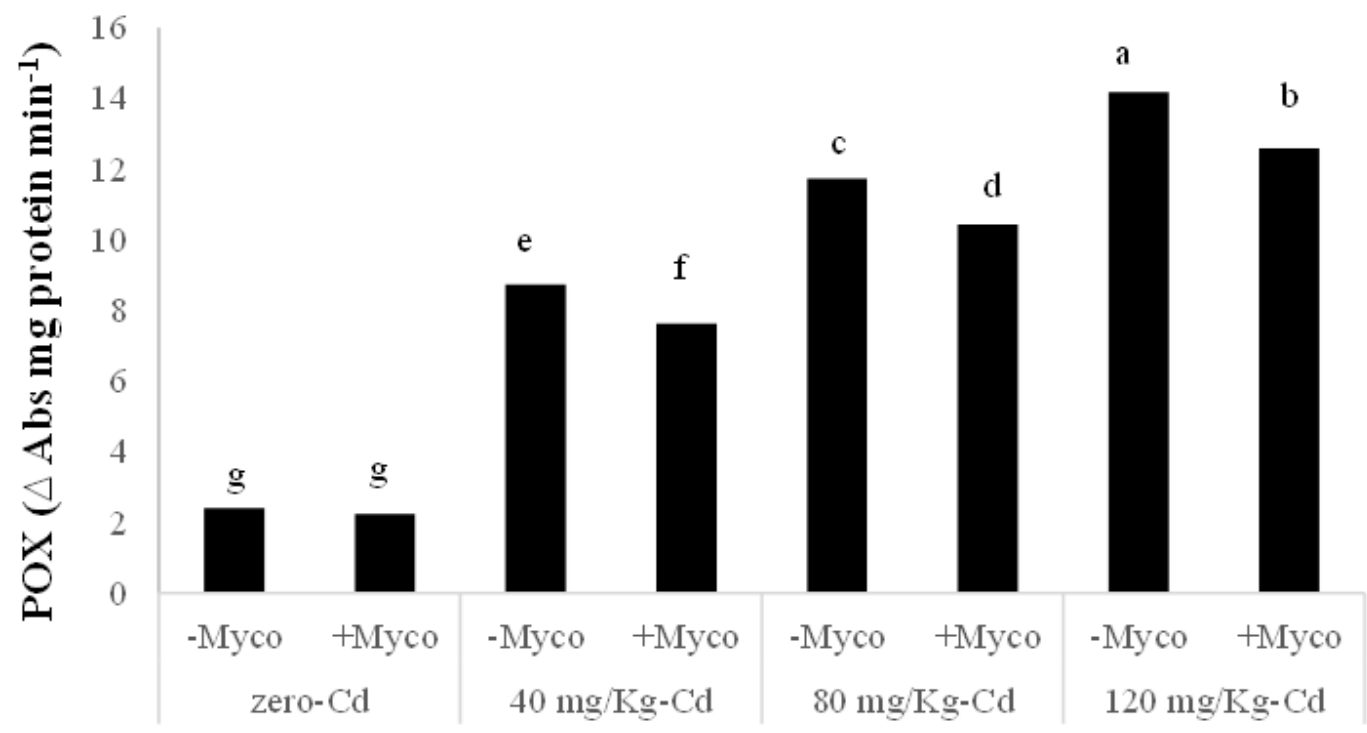

Figure 3. Peroxidae activity of barley grown on Cd polluted soil inoculated with mycorrhizal fungi $\left(-M y c o=\right.$ zero mycorrhizae, + Myco $=$ mycorrhizae applied at $\left.20 \mathrm{~mL} \mathrm{plant}^{-1}\right)$

Table 3. Eigenvalues and principal component factor loading of parameters affected by the interaction between $C d$ and mycorrhizal fungi

\begin{tabular}{c|c|c}
\hline Principal component & PC1 & PC2 \\
\hline Eigenvalues: & 10.782 & 0.996 \\
Variability (\%) & 77.017 & 7.117 \\
Cumulative \% & 77.017 & 84.133 \\
\hline Factor loading & & \\
\hline Height & $\mathbf{0 . 8 8 1}$ & 0.002 \\
Number of grain & $\mathbf{0 . 6 2 9}$ & 0.003 \\
1000 seed weight & $\mathbf{0 . 8 3 2}$ & 0.019 \\
DM & $\mathbf{0 . 6 2 4}$ & 0.006 \\
Chlorophyll & $\mathbf{0 . 8 5 3}$ & 0.000 \\
Proline & $\mathbf{0 . 9 4 9}$ & 0.004 \\
SOD & $\mathbf{0 . 9 2 7}$ & 0.027 \\
CAT & $\mathbf{0 . 9 3 1}$ & 0.003 \\
P & $\mathbf{0 . 5 4 0}$ & 0.001 \\
POX & $\mathbf{0 . 9 4 7}$ & 0.029 \\
LAI & $\mathbf{0 . 9 5 6}$ & 0.015 \\
MDA & $\mathbf{0 . 6 3 2}$ & 0.023 \\
Cadmium & $\mathbf{0 . 9 6 2}$ & 0.011 \\
Colonization & 0.119 & $\mathbf{0 . 8 5 4}$ \\
\hline
\end{tabular}


Biplot (axes PC1 and PC2: 84,13\%)

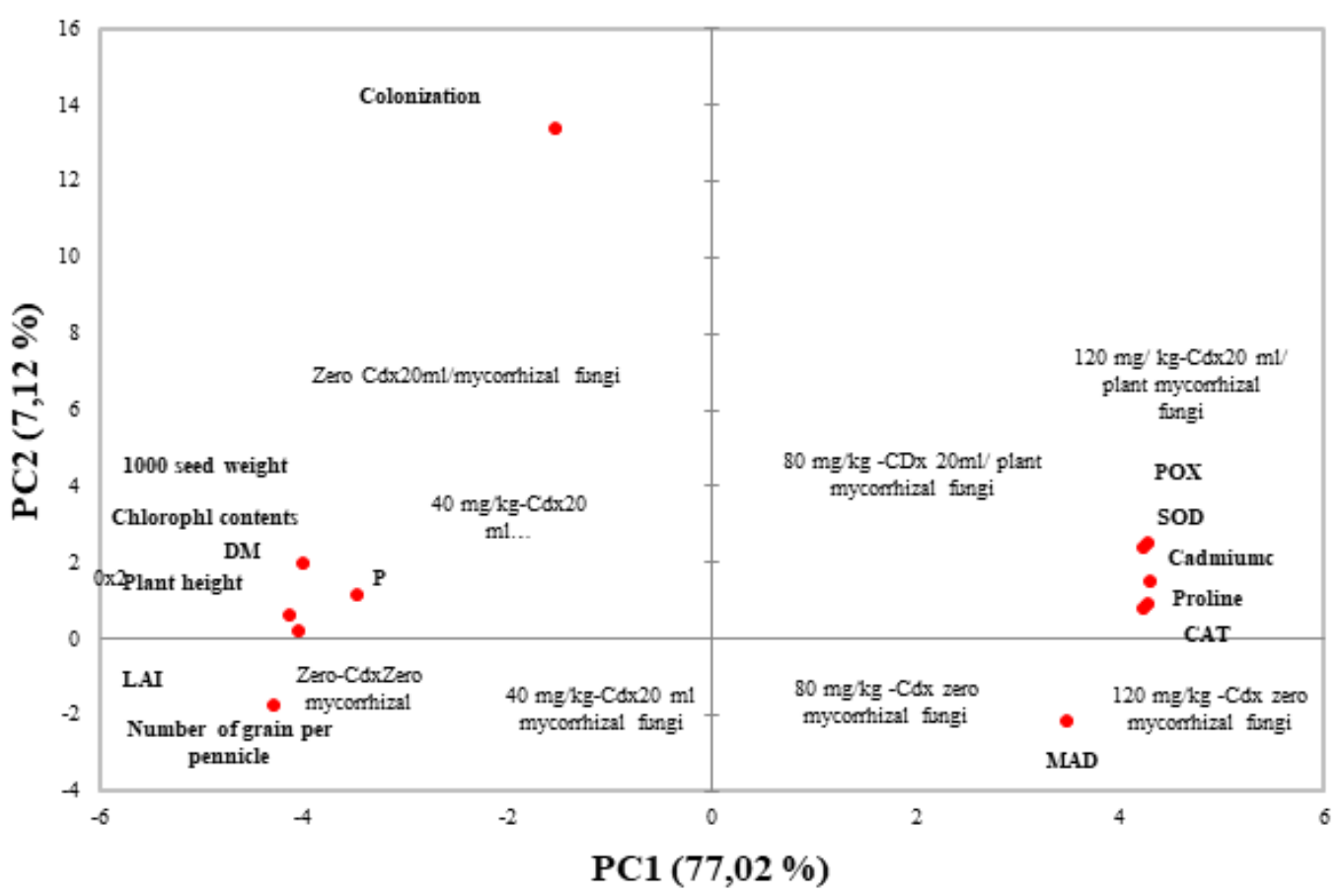

Figure 4. Rotated principal component loadings of agronomic and physiological attributes of barley affected by the interaction between $\mathrm{Cd}$ and mycorrhizal fungi

\section{Conclusion}

Leaf area index, 1000 seed weight, and dry mass of barley were affected by $\mathrm{Cd}$. At the same time chlorophyll and leaf $\mathrm{P}$ were decreased and with a subsequent increase was observed in proline, superoxide dismutase, catalase, and peroxidase activity in leaves. The use of mycorrhizae under cadmium contaminated conditions improved yield attributes of barley. Therefore, future studies must focus on testing this effect under field conditions before the use of AMF on Cd contaminated soils can be recommended.

\section{REFERENCES}

[1] Al-Agely, A., Sylvia, D. M., Ma, L. Q. (2005): Mycorrhizae increase arsenic uptake by the hyperaccumulator Chinese brake fern (Pteris vittata L.). - J Environ Qual 34(6): 21812186. doi: 10.2134/jeq2004.0411.

[2] Arnon, D. I. (1949): Copper enzymes in isolated chloroplasts. Polyphenoloxidase in Beta vulgaris. - Plant Physiology 24: 1-15. http://dx.doi.org/10.1104/pp.24.1.1.

[3] Azcon-Aguilar, C., Cantos, M., Troncoso, A., Barea, J. M. (1997): Beneficial effect of arbuscular mycorrhizas on acclimatization of micropropagated plantlets. - Scientia Horticulturae 72: 63-71. http://dx.doi.org/10.1016/S0304-4238(97)00120-9.

[4] Bano, S. A., Ashfaq, D. (2013): Role of mycorrhiza to reduce heavy metal stress. - Natural Science 5(12): 16-20. DOI: 10.4236/ns.2013.512A003.

[5] Bates, L. S., Waldern, R. P., Teave, I. D. (1973): Rapid determination of free proline for water stress studies. - Plant and Soil 39: 205-207. http://dx.doi.org/10.1007/BF00018060. 
[6] Cakmak, I., Horst, W. (1991): Effect of aluminum on lipid peroxidation, superoxide dismutase, catalase and peroxidase activities in root tip of soybean (Glycine max L.). Plant Physiology 83: 463-468. https://doi.org/10.1111/j.1399-3054.1991.tb00121.x.

[7] Cozzolino, V., Pigna, M., Di Meo, V., Caporale, A. G., Violante, A. (2010): Effects of arbuscular mycorrhizal inoculation and phosphorus supply on the growth of Lactuca sativa L. and arsenic and phosphorus availability in an arsenic polluted soil under non-sterile conditions. - App. Soil Eco. 45: 262-268. https://doi.org/10.1016/j.apsoil.2010.05.001.

[8] De Vos, C., Schat, H., De Waal, M., Vooijs, R., Ernst, W. (1991): Increased to copperinduced damage of the root plasma membrane in copper tolerant Silene cucubalus. - Plant Physiol. 82: 523-528. doi:abs/10.1111/j.1399-3054.1991.tb02942.x.

[9] Dhir, B., Sharmila, P., Saradhi, P. P., Nasim, S. A. (2009): Physiological and antioxidantresponses of Salvinia natans exposed to chromium-rich wastewater. Ecotoxicology and Environmental Safety 72(6): 1790-1797. doi:10.1016/j.ecoenv. 2009.03.015.

[10] Ebenebe, P. C., Shale, K., Sedibe, M. M., Tikilili, P., Achilonu, M. C. (2017): South African mine effluents: Heavy metal pollution and impact on the ecosystem. - Int. J. Chem. Sci. 15: 198-208.

[11] Gadd, G. M. (2004): Microbial onfluence on metal mobility and application for bioremediation. - Geoderma 122: 109-119. doi:10.1016/j.geoderma.2004.01.002.

[12] Galas-Gorcher, H. (1991): Dietary intake of pesticide residues: Cadmium, mercury and lead. - J Food add Contam. 8: 79-80.

[13] Garg, N., Singla, P., Bhandari, P. (2015): Metal uptake, oxidative metabolism, and mycorrhization in pigeonpea and pea under arsenic and cadmium stress. - Turk. J. Agri. Forest. 39: 234-250. https://doi.org/10.3906/tar-1406-121.

[14] Ghanati, F., Morita, A., Yokota, H. (2002): Induction of suberin and increase of liginin content by exess boron in tobacco cell. Soil Science. - Plant Nutri. 48: 357-364. doi: 10.1104/pp.59.2.309.

[15] Giannopolitis, C., Ries, S. (1977): Superoxide dismutases. I. Occurence in higher plant. Plant Physiol. 59: 309-314.

[16] González-Chávez, M. C., Carrillo-González, R., Wright, S. F., Nichols, K. A. (2004): The role of glomalin, a protein produced by arbuscular mycorrhizal fungi, in sequestering potentially toxic elements. - Environmental Pollution 130: 17-323. https://doi.org/10.1016/j.envpol.2004.01.004.

[17] Hildebrandt, U., Regvar, M., Bothe, H. (2007): Arbuscular mycorrhiza and heavy metal tolerance. - Phytochemistry 68: 139-146. 10.1016/j.phytochem.2006.09.023.

[18] Jahromi, F., Aroca, R., Porcel, R., Ruiz-Lozano, J. M. (2008): Influence of salinity on the in vitro development of Glomus intraradices and on the in vivo physiological and molecular responses of mycorrhizal lettuce plants. - Microbial Eco. 55: 45-53. https://doi.org/10.1007/s00248-007-9249-7.

[19] Javaid, A. (2009): Arbuscular mycorrhizal mediated nutrition in plants. - Journal of Plant Nutrition 32: 1595-1618. http://dx.doi.org/10.1080/01904160903150875.

[20] Keshavarz, H., Modarres-Sanavy, S. A. M., Sadegh Gol-Moghadam, R. (2016): Impact of foliar application with Salicylic Acid on Biochemical Characters of Canola Plants under Cold Stress Condition. - Not. Sci. Biol. 8(1): 98-105. https://doi.org/10.15835/nsb.8.1.9766.

[21] Keshavarz, H. (2020): Study of water deficit conditions and beneficial microbes on the oil quality and agronomic traits of canola (Brassica napus L.). - Grasas Y Aceites. 71(3): e373. https://doi.org/10.3989/gya.0572191.

[22] Khatun, S., Ali, M. B., Hahn, E. J., Paek, K. Y. (2008): Cooper toxicity in Withania somnifera: Growth and antioxidant enzymes responses of in vitro grown plants. - Environ. Exp. Bot. 64: 279-285. http://dx.doi.org/10.1016/j.envexpbot.2008.02.004.

[23] Neumann, E., George, E. (2005): Does the presence of arbuscular mycorrhizal fungi influence growth and nutrient uptake of a wild-type tomato cultivar and a mycorrhiza- 
defective mutant, cultivated with roots sharing the same soil volume? - New Phytol. 166(2): 601-609. https://doi.org/10.1111/j.1469-8137.2005.01351.x.

[24] Pandey, N., Sharma, C. P. (2002): Effect of heavy metals $\mathrm{CO}_{2}{ }^{+}, \mathrm{Ni}^{2+}$ and $\mathrm{Cd}^{2+}$ on growth and metabolism of cabbage. - Plant Sci. 163: 753-758. doi:10.1016/S0168-9452(02)002108.

[25] Parlak, K. U. (2016): Effect of nickel on growth and biochemical characteristicsof wheat (Triticum aestivum L.) seedlings. - NJAS - Wageningen J. Life Sci. 76: 1-5. https://doi.org/10.1016/j.njas.2012.07.001.

[26] Pereira, E., Coelho, V., Tavares, R. M., Lino-Neto, T., Baptista, P. (2012): Effect of competitive interactions between ectomycorrhizal and saprotrophic fungi on Castanea sativa performance. - Mycorrhiza 22: 41-49. doi:10.1007/s00572-011-0379-x.

[27] Pharudi, J. A. (2010): Effect of mycorrhizal inoculation and phosphorus levels on growth and yield of wheat and maize crops grown on a phosphorus deficient sandy soil. - MSc, Agric (Agronomy) dissertation, University of Stellenbosch, South Africa.

[28] Qiu, L., Bi, Y., Jiang, B., Wang, Z., Zhang, Y., Zhakypbek, Y. (2018): Arbuscular mycorrhizal fungi ameliorate the chemical properties and enzyme activities of rhizosphere soil in reclaimed mining subsidence in northwestern China. - J. Arid Land 11: 135-147. https://doi.org/10.1007/s40333-018-0019-9.

[29] Shi, G., Ma, H., Chen, Y., Liu, H., Song, G., Cai, Q., Lou, L., Rengel, Z. (2019): Low arsenate influx rate and high phosphorus concentration in wheat (Triticum aestivum L.): a mechanism for arsenate tolerance in wheat plants. - Chemosphere 214: 94-102. 10.1016/j.chemosphere.2018.09.090.

[30] Tavakkoli, L., Khanjani, N. (2016): Environmental and occupational exposure to cadmium in Iran: A systematic review. - Rev. Environ. Health 31(4): 457-463. doi: 10.1515/reveh2016-0042. PMID: 27902453.

[31] Tohidi-Moghadam, H. R. (2017): Super absorbent polymer mitigates deleterious effects of arsenic in wheat. - Rhizosphere 3: 40-43. 10.1016/j.rhisph.2016.12.003.

[32] Tripathi, R. D., Tripathi, P., Dwivedi, S., Kumar, A., Mishra, A., Chauhan, P. S., Norton, G. J., Nautiyal, C. S. (2014): Roles for root iron plaque in sequestration and uptake of heavy metals and metalloids in aquatic and wetland plants. - Metallomics 6: 1789-1800. https://doi.org/10.1039/C4MT00111G.

[33] Ullah, H. A. (2016): Alleviating effect of exogenousm application of ascorbic acid on growth and mineral nutrients in cadmium stressed barley (Hordeum vulgare) seedlings. Int. J. Agri. Biol. Faisalabad 18: 73-79.

[34] Wang, H. Y., Wen, S. L., Chen, P., Zhang, L., Cen, K., Sun, G. X. (2016): Mitigation of cadmium and cadmium in rice grain by applying different silicon fertilizers in contaminated fields. - Environ. Sci. Pollution Res. 23: 3781-3788. doi:10.1007/s11356-015-5638-5.

[35] WHO. (2000): Cadmium. - Air Quality Guidelines - Second Edition. Chapter 6.3. WHO Regional Office for Europe, Copenhagen, Denmark.

[36] Zhao, F. J., McGrath, S. P., Meharg, A. A. (2010): Arsenic as a food chain contaminant: mechanisms of plant uptake and metabolism and mitigation strategies. - Annu. Rev. Plant Biol. 61: 535-559. https://doi.org/10.1146/annurev-arplant-042809-112152. 